Nr 3(60), 2019, s. 405-411

https://doi.org/10.12797/Politeja.16.2019.60.25

\title{
Jacek BARTYZEL
}

Uniwersytet Mikołaja Kopernika w Toruniu

bartyzel@umk.pl

\section{INNY BOBRZYŃSKI}

\section{SEBASTIAN PACZOS, JAN BOBRZYŃSKI. PORTRET POLITYCZNY}

\author{
Wydawnictwo UAM, Poznań 2018, 408 s.
}

Jan Bobrzyński (1882-1951) to jedna z tych postaci w dziejach polskiego konserwatyzmu, z którą Muza historii - Klio obeszła się wyjątkowo (i niezasłużenie) niełaskawie. Praprzyczyną tego losu był fakt obiektywny, na który sam zainteresowany nie mógł mieć żadnego wpływu - a zatem, można rzec za prof. Bogusławem Wolniewiczem, tychiczny - czyli urodzenie się jako syn wybitnego oraz powszechnie znanego i szanowanego uczonego i polityka, Michała Bobrzyńskiego (1849-1935), przytłaczającego go swoim autorytetem, w którego cieniu Jan pozostawał nie tylko przez całe niemal życie, ale również po śmierci. Drugim powodem było to, że z ruchem konserwatywnym związał się on dopiero wtedy, kiedy konserwatyzm polski przeżywał już swój łabędzi śpiew, nie będąc z różnych powodów zdolny do odgrywania roli samodzielnej, a jedynie swoistej grupy nacisku w łonie bardzo zróżnicowanego obozu sanacyjnego, którego jedynym spoiwem była „ideologia państwowa” spersonalizowana poparciem dla nieformalnego dyktatora, marszałka Józefa Piłsudskiego. Jan Bobrzyński, jako sekretarz generalny „stańczykowskiego” Stronnictwa Prawicy Narodowej, od 1926 roku z energią pracował nad tym, aby ocalić ideową tożsamość konserwatystów oraz przekuć współpracę z obozem rządzącym w realny i suwerenny wkład zachowawców do przebudowy wadliwego, demokratyczno-parlamentarnego ustroju. Jednak, nie napotkawszy w tym ani zrozumienia, ani wsparcia swoich arystokratycznych mocodawców, walkę tę przegrał i po 1934 roku zrezygnował z formalnej przynależności do stronnictwa konserwatywnego, zakładając natomiast miniaturowy Związek Polskiej Myśli Państwowej. W efekcie tej izolacji i zupełnego zapomnienia w ostatnim okresie życia, nawet wówczas, kiedy (od mniej więcej lat 70. ubiegłego wieku) zaczęto poważne studia nad działalnością i myślą konserwatyzmu w II Rzeczypospolitej, jego nazwisko wprawdzie 
musiało pojawiać się we wszystkich opracowaniach, ale rzadko doceniano jego aktywność, a przede wszystkim niemały przecież i często wykraczający poza kwestie doraźne dorobek publicystyczny. Niektóre opinie (jak na przykład Marcina Króla) były wręcz lekceważące i sprowadzały się do ogólników o epigonizmie, antykwaryzmie i po prostu nudzie jego publicystyki. W tej sytuacji pojawienie się na rynku wydawniczym pełnej biografii politycznej, zawierającej także analizę myśli Jana Bobrzyńskiego, pióra poznańskiego historyka Sebastiana Paczosa, należy uznać za objaw „immanentnej sprawiedliwości”, przywracającej świadomości zbiorowej dorobek tego nietuzinkowego działacza i myśliciela, który chciał wybić konserwatyzm w Polsce na niepodległość.

Swój cel poznawczy Sebastian Paczos określa jako prześledzenie aktywności Jana Bobrzyńskiego na różnych polach dziatalności publicznej oraz przywrócenie myśli politycznej tegoż autora należnego jej miejsca w historiografii myśli zachowawczej, na które $z$ pewnościa zastuguje (s. 11). Zasadniczym pytaniem jest dla niego to, na ile jego [Bobrzyńskiego] myśl różnita się od pogląów innych konserwatystów, a na ile byta z nimi zbieżna?, szczegółowymi zaś: w jakim stopniu można uznać Bobrzyńskiego za kontynuatora myśli stańczyków? Na ile jego koncepcje polityki zagranicznej i utożenia stosunków $z$ mniejszościami, zwtaszcza ukraińska, odbiegaty od propozycji wychodzacych $z$ innych środowisk zachowawczych? Czy myśl mocarstwowa gtoszona przez Bobrzyńskiego opierata sie w zasadzie na tych samych wytycznych co innych zwolenników mocarstwowości? Czy jego poglady gospodarcze odznaczaty się oryginalnościa? Jakie przekonania legty u podstaw tak zdecydowanego odrzucenia demokracji? (tamże). Autor konstatuje też dwuwarstwowość większości koncepcji Bobrzyńskiego, czyli to, że z jednej strony - treść jego postulatów, wartości i idei jest niejednokrotnie konsekwencja wywodzenia się z konserwatywnego środowiska i chęcią kontynuowania tradycji tego ruchu, z drugiej zaś - że można dostrzec u niego uleganie pokusom unowocześniania myśli konserwatywnej wedle wzorów zachodnich (tamże). Nie precyzuje jednak, o jakie wzory chodzi.

Paczos stwierdza, iż jego praca ma konstrukcję problemową, a tematyka poszczególnych rozdziatów podyktowana byta przede wszystkim specyfika myśli Jana Bobrzyńskiego (s. 17). Przypatrując się układowi treści książki, można zgodzić się z zawartym w niej pogrupowaniem problemów, w którym narracja przechodzi od biografii portretowanej postaci i jej usytuowania w rzeczywistości ideowej jej środowiska (konserwatystów) oraz kontekstualnych realiów politycznych (rządy sanacyjne) do tematów przewodnich Bobrzyńskiego w obszarze myśli gospodarczej, ustrojowej i geopolitycznej. Zadowalająca jest także baza źródłowa recenzowanej monografii. Prócz, co oczywiste, publicystyki Jana Bobrzyńskiego, obficie wyzyskane poznawczo zostały źródła archiwalne i niepublikowane: pamiętniki bohatera rozprawy i jego żony, korespondencja, zasoby prywatne rodziny (zwłaszcza wnuka Jana - Michała) oraz w ogóle materiały archiwalne dotyczące polskich konserwatystów. Jak widać nie tylko z bibliografii, autor zna i wykorzystał całą istniejącą dotychczas literaturę sekundarną poświęconą Janowi Bobrzyńskiemu (na czele z pracami Włodzimierza Micha i Edwarda Czapiewskiego) oraz konserwatyzmowi polskiemu i myśli politycznej w II Rzeczypospolitej. Z przykrością muszę jedynie odnotować to, że cytując obficie również moją książkę, której jeden z (trzech) rozdziałów poświęcony był właśnie Janowi Bobrzyńskiemu, notorycznie 
błędnie zapisuje jej tytuł (Konserwatyzm bez kompromisów zamiast Konserwatyzm bez kompromisu), co wprawdzie merytorycznie wiele nie zmienia, niemniej świadczy o pewnym niechlujstwie warsztatowym.

Lektura książki Sebastiana Paczosa unaocznia, że dwoma głównymi problemami badawczymi, z którymi autor musiał się zmierzyć, były: 1) czy i na ile Jan Bobrzyński był w każdym etapie swojej aktywności intelektualno-politycznej konserwatystą, oraz 2) czy i w jakim stopniu był on również liberałem, przynajmniej w ekonomicznym aspekcie tej ideologii. Trzeba tu od razu zaznaczyć, że są to kwestie trudne do jednoznacznego rozstrzygnięcia, toteż w omawianej rozprawie dostrzec można liczne wahania, a niekiedy nawet i sądy kontradyktoryjne, więc na nich właśnie skoncentrujemy naszą uwagę.

Co się tyczy pierwszej kwestii, autor rozpoczyna od zarysowania wątpliwości, $c z y$ poglady Jana Bobrzyńskiego nie leża gdzieś na pograniczu ruchu konserwatywnego lub panstwowego, monarchistycznego czy też liberalnego. Jest to efektem ztożoności i pewnej nieokreśloności konserwatyzmu, sytuującego się pomiędzy wyraźnie skrystalizowanymi stanowiskami (s. 15). Już w tym momencie można zauważyć, że problem został postawiony nieco wadliwie, albowiem nie istnieje jakaś presupozycyjna kontradyktoryjność pomiędzy konserwatyzmem a monarchizmem (preferencja dla monarchii jest przecież stanowiskiem typowym dla konserwatyzmu, wyjąwszy kraje pozbawione tradycji monarchicznej, jak Szwajcaria czy USA) ani nastawieniem propaństwowym, ergo - trudno też zgodzić się z twierdzeniem, iż konserwatyzm per se jest nieokreślony oraz sytuuje się pomiędzy wyraźnie skrystalizowanymi stanowiskami, które w dodatku (te wymienione) wcale nie są antynomiczne, ponieważ antynomia istnieje pomiędzy monarchizmem a republikanizmem, a nie między monarchizmem a konserwatyzmem czy nawet liberalizmem (współczesne monarchie są nawet $\mathrm{z}$ reguły liberalne) albo pomiędzy konserwatyzmem a liberalizmem, nie zaś pomiędzy liberalizmem a czymś tu w ogóle nienazwanym, względem czego konserwatyzm byłby „pośrodku”.

Dalej autor oświadcza: odwotując się do stosowanych w historiografii kryteriów (bazy spotecznej, samooceny oraz oceny pozostatych cztonków środowiska), stanątem na stanowisku uznajacym Jana Bobrzyńskiego za konserwatystę (s. 15), potwierdzając to też w dalszych partiach tekstu - przykładowo: Bobrzyński nigdy nie wyrzekt się swiatopogladu konserwatywnego (s. 160); Bobrzyński nie przestat być konserwatysta i nie stat sie państwowcem z dnia na dzień. Oba sposoby myślenia wzajemnie przenikaty sięprzez lata w jego publicystyce, zarówno przed, jak i po 1934 roku (s. 189-190), atoli jednym tchem niejako oznajmia coś zgoła przeciwnego, ponieważ: poświęcając się dążeniom do odrodzenia myśli konserwatywnej, [Bobrzyński] uwiktat się w sprawy, które przyczynity się do jego ostatecznego zerwania z ruchem konserwatywnym (s. 160) oraz: Już jako redaktor "Naszej Przysztości” zacząt kwestionować metodę konserwatywnego myślenia, uznajac ja za przejaw bierności i oportunizmu ideowego (s. 191), aby wreszcie uwieńczyć to w Zakończeniu sugestią „heretyckości” poglądów Bobrzyńskiego względem konserwatyzmu i wyjątkowo niejasnym, niestety, zdaniem: Jego myśl konserwatywna znajdowata się na linii biegnacej w poprzek dziejów (s. 375). Wprawdzie Sebastian Paczos trafnie rozpoznaje - wplatając $\mathrm{w}$ tok własnej narracji nieotwarty cudzysłowem cytat 
z mojej książki - powód, dla którego Bobrzyński oddalił się od stronnictwa konserwatywnego, a zbliżył do prawicy piłsudczykowskiej (Ewolucjępogladów Bobrzyńskiego można ttumaczyć jego przeświadczeniem o sprzeniewierzeniu się przez konserwatystów ich wtasnej filozofii politycznej. Skoro konserwatyści nie zastugiwali już na to miano, a putkownicy nauczyli się myśleć kategoriami państwowymi, to $w$ istocie im przystuguje miano "prawdziwych konserwatystów", s. 191), to jednak wydaje się, że jego kłopot z interpretacją tej kwestii bierze się z niedostatecznie ostrego rozróżniania dwóch płaszczyzn: czyjegoś usytuowania w obszarze filozofii politycznej konserwatyzmu oraz usytuowania w obszarze polityki konkretnego ruchu konserwatywnego. Można przecież być konsekwentnym konserwatystą jako myśliciel polityczny, a pozostawać czy znaleźć się w sporze z partią konserwatywną działającą w danym czasie i miejscu, a to właśnie był przypadek Bobrzyńskiego. Tej dystynkcji w studium Paczosa mi brakuje.

Drugą problematyczną kwestią w recenzowanej pracy jest sprawa liberalizmu, która zresztą wielorako wiąże się z tą poruszaną wyżej. Autor stawia tutaj szereg mocnych w moim odczuciu nazbyt mocnych - tez, z których jednak co rusz się wycofuje albo przynajmniej je w znacznym stopniu relatywizuje. Znamienne jest już samo zatytułowanie rozdziału dotyczącego poglądów Jana Bobrzyńskiego na sprawy ekonomiczne Liberalizm w gospodarce. Tenże liberalizm Bobrzyńskiego opierat się na dwóch kardynalnych wartościach: wolności i wtasności. Wolność wiąat z indywidualizmem i byta ona dla niego gwarancją nieskrępowanego rozwoju jednostki (s. 233). Można wszelako od razu zauważyć, że obie te wartości cenione są też zazwyczaj przez konserwatystów (o czym zresztą autor napomyka - zob. s. 370), co nie znaczy jednak, że są przez nich rozumiane tak samo, jak przez liberałów. Zdaniem Sebastiana Paczosa, poglady Bobrzyńskiego na wtasność wywodza się z liberalizmu klasycznego, gdzie wtasność jest uznawana za prawo naturalne każdego cztowieka, warunkujace jego wolność i stanowi podstawe wolnego spoteczeństwa (s. 237). W tym miejscu jednak znów brakuje wyjaśnienia różnicy pomiędzy liberalnie (w klasycznym ujęciu Johna Locke'a) rozumianymi, to znaczy jako podmiotowe uprawnienia jednostki, „prawami naturalnymi” (natural rights) a klasycznym, czyli przedmiotowym jusnaturalizmem jako prawem moralnym ustanowionym dla człowieka przez Boga. Jeszcze dalej autor posuwa się w interpretowaniu przedstawianego przez Bobrzyńskiego programu Zjednoczonego Frontu Gospodarczego, który jego zdaniem postulowat skrajnie indywidualistyczna wolna konkurencje (s. 225-226). W poglądzie na kreowanie dobrobytu społecznego miał też Bobrzyński być wręcz skrajnym liberatem, uważat bowiem dobro ogólne za sumę interesów jednostek, powstające jako wypadkowa ich egoistycznych dziatañ (s. 231).

W innych miejscach natomiast autor osłabia swoje sądy, zauważając na przykład, że Bobrzyński byt liberatem w ekonomicznym, a nie politycznym znaczeniu. Nie ujmowat liberalizmu doktrynalnie, dązac do stworzenia programu gospodarczego dopasowanego do polskich realiów. U podstaw jego poglądów ekonomicznych leżata idea wolności. Ale byt to liberalizm pragmatyczny, nie trzymajacy się sztywno wytworzonej $w$ danym czasie treści i oparty na tradycyjnych wartościach (s. 255-256). W szczególności zaś złagodzenie stanowiska Bobrzyńskiego miało być reakcją na wybuch kryzysu gospodarczego. To przypuszczenie nie wydaje się jednak mocno uzasadnione, albowiem trudno wskazać 
logiczny związek pomiędzy bolączkami społecznymi wynikłymi z kryzysu gospodarczego a wskazanymi (słusznie) przez autora rozprawy pierwiastkami ideologicznymi liberalizmu „integralnego”, które Bobrzyński odrzucał zawsze i niezależnie od kryzysu: jego demokratycznym podłożem, catkowita swobodą sumienia i dominacją wartości materialnych (s. 232). Inną jeszcze aporię w interpretowaniu poglądów Bobrzyńskiego dostrzec można w wysunięciu z jednej strony tezy, iż Bobrzyński traktuje naród jako osobę zbiorowa, a nie jako ogót ludzi, będących suma pierwotnie suwerennych jednostek (s. 285), z drugiej zaś - że Bobrzyński wprawdzie akceptowat koncepcje organicystyczna, która należy do kanonu zasad konserwatywnych, ale jego sympatia do liberalizmu sprawita, że definiowat spoteczeństwo jako sumę jednostek, jednocześnie starają się unikać wszelkich zatożeń metafizycznych (s. 334-335). Nawet jeśli przyjmiemy, że społeczeństwo i naród nie są jednym i tym samym, to jednak definiowanie pierwszego jako sumy jednostek, drugiego zaś jako osoby zbiorowej nie brzmi przekonująco.

Próbą rozwiązania przez autora rozprawy tej i innych aporii idei Bobrzyńskiego jest wielokrotnie powtarzana myśl o swoistej próbie syntezy wartości konserwatywnych i liberalnych (przykładowo:Jego konserwatyzm bytswoistym potaczeniem liberalizmu zzasadami wynikającymi z religii katolickiej, zwtaszcza chrześcijańskiej moralności, s. 149; Myśl Jana Bobrzyńskiego oparta byta na konserwatyzmie spotecznym i liberalizmie ekonomicznym, s. 376; „Neokonserwatyzm” Jana Bobrzyńskiego byt dopetnieniem dawnego konserwatyzmu nowymi zasadami, wśród których na pierwszy plan wysunąt zasady liberalizmu ekonomicznego i mocarstwowości, s. 376; [...] mamy do czynienia z programem inspirowanym wartościami konserwatywnymi, gdzie celem jest budowa spoteczeństwa w zasadzie liberalnego, s. 380), a także liberalizmu z nauką społeczną Kościoła ( $\mathrm{Na}$ utrzymane $w$ duchu integralnego liberalizmu postulaty [Bobrzyński] naktadat ograniczenia wynikające z zasad moralności chrześcijańskiej. W przypadku stosunków pracy byta to zasada solidaryzmu i postulat przebudowy struktury gospodarki państwa wedtug wytycznych zawartych w encyklice papieskiej Quadragesimo anno, czyli zmierzajacych do ustroju korporacyjnego, s. 250). Dobitną rekapitulację tej próby znajdujemy w konkluzji: Próbując przyporządkować Jana Bobrzyńskiego do któregośz klasycznych nurtów myśli politycznej, określitbym go mianem liberalizującego konserwatysty. Od akceptacji w petni liberalizmu dzielit go zarówno antyindywidualizm, jak i szersza rola państwa, zwtaszcza poza sfera ekonomiczna. W odróżnieniu zaś od wielu konserwatystów ktadt on większy nacisk na prawa wolnościowe jednostki (zwtaszcza w sferze gospodarczej), a jego poglady spoteczno-ekonomiczne odbiegaty już dość znacznie w stronę liberalizmu (s. 370). Z tym końcowym wnioskiem należy się zgodzić, ale właśnie dlatego poprzednie konstatacje o liberalizmie wydają się zbyt daleko idące.

Całkowicie natomiast odrzucić należy - skądinąd pojawiające się jakby znienacka i w żaden sposób nieumotywowane - twierdzenie, iż Jan Bobrzyński przypomina trochę niemieckich rewolucyjnych konserwatystów - nie tyle w sensie ideowym (może poza krytyką demokracji), ile raczej mentalnie (s. 381). Otóż właśnie mentalnie światy ideowe rewolucyjnych konserwatystów z epoki weimarskiej oraz Bobrzyńskiego są z zupełnie innych galaktyk. Z drugiej strony, co najmniej przesadzone jest też twierdzenie, iż w swoich koncepcjach Jan Bobrzyński nawiązywat do darwinizmu spotecznego (s. 331). 
Całkowicie odrzucić należy twierdzenie iż Stanisław Cat-Mackiewicz był niekwestionowanym liderem wileńskich „żubrów” (s. 97). Pozycja Cata - człowieka ówcześnie młodego, bez pozycji społecznej i majątku, wprawdzie legitymującego się „starożytnym” klejnotem szlachectwa, to jednak „chudopachołka”, co w tym ziemiańsko-arystokratycznym kręgu miało ogromne znaczenie - wynikająca z jego talentu i płodności publicystycznej była zupełnie inna: otrzymał pewną autonomię jako redaktor „Słowa” od jego fundatorów, często sprawiał im kłopoty swoimi wyskokami, będąc prawdziwym enfant terrible, ale kierownictwo polityczne grupy spoczywało bez wątpienia w rękach ludzi starszych i z autorytetem, jak Aleksander Meysztowicz, Stanisław Wańkowicz, Marian Broel-Plater, Albrecht Radziwiłł i Eustachy Sapieha. Mocno sporne jest określanie profesorów Edwarda Dubanowicza i Ignacego Czumy jako konserwatystów (s. 260). Owszem, obaj mieli poglądy prawicowe, niemniej pierwszy był działaczem Stronnictwa Chrześcijańsko-Narodowego i to tej jego części, która faktycznie była bliższa endecji aniżeli konserwatystom, drugi zaś był działaczem Stronnictwa Katolicko-Ludowego oraz sanatorem.

W książce Paczosa napotykamy pewną liczbę stwierdzeń nieraz sprawiających wrażenie luźno rzuconych uwag, które jednak brzmią zagadkowo i pozostawiają niedosyt informacyjny bądź brakuje ich wyjaśnienia. Dlaczego na przykład współpraca w okresie II wojny światowej z Kazimierzem Marianem Morawskim miała świadczyć o zagubieniu ideowym Bobrzyńskiego (s. 61), skoro Morawski był niewątpliwie też konserwatystą (i monarchistą) oraz przez wiele lat (jeszcze od 1914 roku) działaczem Stronnictwa Prawicy Narodowej, zanim je (w 1922 roku) opuścił, zakładając Stronnictwo Zachowawcze, nadto zaś obaj panowie znali się jeszcze ze studiów na Uniwersytecie Jagiellońskim, o czym autor sam wspomina (s. 25), choć chyba później o tym zapomniał. Czy z kolei nie było żadnej możliwości weryfikacji niejasnej informacji pochodzącej z pamiętników żony Bobrzyńskiego o wyroku śmierci od podziemia za domniemaną „kolaborację” męża z Niemcami? (s. 58). Żałować wypada, że autor rozprawy nie pokusił się o próbę głębszej analizy powodów (oprócz zagrożenia utratą pracy) wstąpienia w 1947 roku obojga małżonków do Polskiej Partii Socjalistycznej (s. 75), co samo w sobie jest przecież sui generis „ideologicznym horrorem” w wypadku „liberalizującego konserwatysty”. Czy były to tylko powody oportunistyczne, czy też kryła się za tym jakaś ewolucja stanowiska wynikająca z konserwatywnej normy „autonomii rzeczywistości”? Tym bardziej trudno pojąć, co kryje się za enigmatycznym oświadczeniem, że stosunek Marii Bobrzyńskiej do rzeczywistości politycznej po II wojnie światowej byt co najmniej niejednoznaczny (s. 85, przyp. 233). Dla porządku odnotować należy też błędną pisownię nazwiska ekonomisty austriackiego (Misses zamiast Mises, s. 225) oraz wersalskiego pałacyku, w którym dokonano rozbioru Węgier (Triano zamiast Trianon, s. 344).

Powyższe uwagi krytyczne nie powinny atoli rzutować na całościową ocenę omawianej książki. W moim przekonaniu jest to poznawczo wartościowa praca, o rzetelnym warsztacie badawczym oraz poszerzająca stan wiedzy o konserwatyzmie polskim, w szczególności zaś o jego nietuzinkowym i oryginalnym myślicielu oraz (mniej szczęśliwym) polityku. Na szczególne uznanie zasługuje analiza przyczyn krytycznego 
stosunku Jana Bobrzyńskiego do demokracji oraz jego programu polityki mocarstwowej, w znacznej części także jego koncepcji ustrojowych, wyjąwszy nieco po macoszemu potraktowany problem „monarchizacji ustroju”. Zgodnie z przyjętą metodą badawczą korelowania i przenikania się analizy stylu myślenia politycznego i działalności bohatera rozprawy w określonej rzeczywistości Paczosowi udało się stworzyć także przekonujący portret osoby uwikłanej w dramat życia zbiorowego w trzech jakże różnych - co podkreśla - epokach historii XX-wiecznej Polski. 